\title{
154 Reviews
}

social movements, and it is suggested that both the modern 'death taboo' and the 'classical death of Western nostalgia' are fictive products of the attempt of the 'happy death' movement to identify the 'enemy' which is a necessary feature of such movements. These are shrewd observations, well worth raising for debate.

'Toward a Sociology of Death and Dying' contains seven articles from research which in varying degrees has been grist for 'The Craft of Dying'. Six concern the ways in which officials and professionals organize their dealings with death: doctors in training, nursing and residential home staff, ministers, coroners (or more precisely the officials who announce accidental death to the family), and those responsible for exccutions. Laymen get an occasional look in as patients, residents or clients, but there is only one article, by Sarah Matthews, on the laity in private life, a byproduct of her research on older women. Many of these materials were to some extent previews of books which have appeared subsequently, by Coombs, Lofland, Charmaz, Gubrium, and Matthews; two, by Wood and Marshall, are independent items: but in general an individual assessment would be beside the point.

These volumes succeed in the limited aims with which they set out: to gather new cmpirical materials in the organization of death, 'towards' a sociology of the subject, and to suggest some 'preliminary understandings' arising from them, all more or less within the scope of symbolic interactionism, and all seeking to extend that approach beyond the analysis of hospital dying carried out by interactionists in the sixties. The coverage of the venture is still avowedly far from complete. The incompleteness of the enterprise is, however, in my vicw more seriously suggested by wcaknesses in the interactionist approach itself. The chief of these weaknesses is the reduction of thought, belief and values either to epiphenomena of group activity, or to something in the individual which Lofland terms 'stance', that is 'tone', 'colour' or 'mood' - dying as 'the brave reformer', 'the disabled observer' and so on. There is something altogether too dramaturgical in this, too reminiscent of the formalism of 'characterisation' in literary criticism, too distanced from what it is that makes people act so differently in the face of death. For impression management, for encounters in public places, for group activity among professionals and organizations, including those concerned with death, this approach has suggested much of value. But for sociological accounts of what dying means to individuals, and why, more is needed than interactionists have yet offered.

MRC Medical Sociology Unit, Aberdeen

RORY WILLIAMS

Barbara Myerhoff, Number Our Days, E. P. Dutton, New York, I980. 306 pp. \$12.95. ISBN o 525 I 69555 .

This is a study of the social organization of a Jewish day centre in Southern California, and its significance in the lives of its members. The author spent four years as an anthropologist, researcher, friend and family member (one old man claimed that she was his long-lost granddaughter) immersed in the 
social world of the centre, the benches in front of it, and the boardwalk. Through rich narrative and extensive passages of dialogue, conventional anthropological themes emerge: the importance of ritual, the nature of conflict and its resolution, and the ways in which people make sense of the world.

As the analysis develops, the reader becomes intensely involved in the thoughts and feelings of Basha, Faegl, Gita, Manya, Nathan, Moshe, and other old men and women in their eighties and nineties, former migrants from Eastern Europe. If a lot of space is given to their conversation, recollections and bobbe-myseh (grandmothers' tales), it is because 'the tale certifies the fact of being and gives sense at the same time'. These old men and women, survivors of the holocaust and of their kin and friends, are involved in a constant search for meaning. Their existential problems are a product of their marginal position in American society - elderly, poor, Jewish, far removed both physically and culturally from their origins and out of touch with their successful and assimilated children. The need for solidarity is intensified by their situation in the town, whose Jewish population is contracting rapidly. Other residents show little concern and are sometimes violent in their treatment of the elderly Jews on the boardwalk.

As with all closeknit communities, where people are in contact more through circumstances than choice, there is social conflict in the centre. In the need to talk and be recognized, these people compete fiercely for time and attention. Believing passionately in independence they also compete in giving to the needy, particularly in Israel. The conflict, in its way, keeps them alive: 'we fight to keep warm'.

Myerhoff shows how, through ceremonial events (a graduation ceremony and a birthday party) and conflicts of belief and relationship (the issue of succession to the presidency and a quarrel between two women), the members of the centre reaffirm basic values and achicve a sense of individual and collective continuity. Ritual forms of protest enable them to cope with the many injustices in their lives. Traditional patterns of ceremonial are adapted to present circumstances and used to celebrate their Jewishness and survival in a difficult world.

Number Our Days makes contributions in many areas. As an example of a social anthropologist at work, it is excellent. Mycrhoff describes in detail her entry into the community, and the crisis caused by her sense of guilt over exploiting people in the centre (she calls the technique of guilt arousal, employed frequently by her informants against her and each other, a 'strategy of intimacy'). The application of concepts and insights drawn from social anthropology takes place in discussions, reported verbatim, with a key informant, Schmuel the Tailor.

The book also contributes significantly to the literature of social gerontology, of ethnic minorities, and of women's studies. Through this study we are shown how a group of very old and needy people can be kept in their own homes. We see the effect of migration on ageing, and the ways in which an elderly minority group perpetuates itself as a cultural unit. Finally, Myerhoff analyses the differential impact of the ageing process on men and women. Her account ends as a testament to the strength and vitality of old 
women. Accustomed to managing their own lives and domestic routines; knowing through their experience of menstruation, childbirth and feeding, and the menopause, that the body has a life of its own; used to accepting help from each other; enjoying closer ties with the children whose success counts so highly; and skilled in social relationships; they are able to accept the losses of old age with greater equanimity and resourcefulness than the men. Myerhoff concludes that the 'quiet conviction and satisfaction with themselves' communicated by these women rests on a sct of shared understandings concerning the importance of offering food, producing and raising children, and shaping the atmosphere of the home.

It is in the context of differential ageing that Myerhoff introduces the notion of 'aging as a career'. Emerging from the experiences of the old people themselves, it replaces the usual 'series of losses' notion that younger people often have of ageing. 'Even [the old people] who stated flatly that old age was a curse, with no redeeming features, could be seen living engaged lives, passionate and original. Nearly every person in the community centre men and women - had devised some career, some activity or purpose to which he/she was committed. They had provided themselves with new possibilities to replace those that had been lost, regularly set new standards for themselves in terms of which to measure growth and achievement, sought and found meaning in their lives, in the short run and the long.' (p. 25I) 'And for all of them, getting up each morning, being independent, living up to their goals, despite incredible odds, managing for themselves, whether it was only dressing, cooking, shopping, demanding and getting satisfaction from a hard-hearted or indifferent doctor or welfare official - these, too, should be counted as successful examples of the lifcwork of aging.' (p. 252)

Myerhoff's message (for by the end of the book it has that quality) is that we should take the centre women as models for retirement. For in the rituals of the household, in caring for others, in serious, dedicated friendships, in constructing individual careers made of personally discovered projects, in arranging lives of self-care and attentiveness to others who are needy, they present us with possibilities for our own futures.

It is one thing to agree with Myerhoff that we must all, both men and women, attend to these expressive concerns, in later life if not earlier. It is quite another to do so, lacking the benefit of the centre women's carly training in the shtetls of Eastern Europe (which, Myerhoff convincingly argues, were a crucial factor in shaping their present outlook). Nevertheless, this is a very good book. It has a bearing on several aspects of contemporary ageing and deserves to be widely read.

Centre for Continuing Education,

DOROTHY JERROME

University of Sussex 